UDC 628.1

DOI:

\title{
INCREASING EFFICIENCY OF THE WASTEWATER TREATMENT PLANT OF KHOROL FACTORY FOR BABY FOOD
}

\author{
L.F. Dolina, V.A. Kozachyna \\ Dnipro national university of railway transport named after academician V. Lazaryan, department \\ «Hydraulics and water supply», Dnipro, dolina@pcb.diit.edu.ua
}

\begin{tabular}{|l|}
\hline Article history: \\
Received 23 April 2019 \\
Accepted 30 May 2019 \\
Print 25 June 2019 \\
\hline
\end{tabular}

The aim of the work is to study the efficiency of the wastewater treatment plant at Khorol factory for baby food and to propose ways to improve quality of wastewater treatment. Some pollutants concentration exceeding the maximum permissible concentration for discharges is observed. In order to eliminate this problem, some solutions are proposed. To increase wastewater treatment effectiveness at the plant, recirculation of wastewaters and replacement of current filling material of the tower biofilters with plastic plate blocks is proposed.

Key words: wastewater treatment plant, biological treatment, reconstruction, treatment efficiency improvement.

\section{Introduction.}

Wastewater treatment plant of Khorol factory for baby food takes wastewater from the factory itself, veterinary and sanitary plant and town sewage. Total daily amount of wastewater is about $1000 \mathrm{~m}^{3}$. Complex of biological wastewater treatment facilities consists of (Fig. 1) receiving chamber, radial grit chamber with circular motion of water, clarifier-digester (with natural aeration), tower biofilters, secondary settlers, chlorinator for water disinfection with sodium hypochlorite usage and contact tanks, sand and sludge drying beds. Control over the efficiency of treatment facilities is based on the results of chemical analyzes of the laboratory, located on the territory of the plant.

For the treatment facilities of Khorol factory for baby food, which discharges purified water in the marshland of the Khorol River, the maximum permissible concentrations for discharge are set out in Table 1.

Table 1 - Maximum permissible concentrations for discharges of Khorol factory for baby food

\begin{tabular}{|c|l|c|c|}
\hline \multirow{2}{*}{$№$} & \multicolumn{1}{|c|}{ Pollutants } & Unit of measurement & Concentration of pollutants \\
\hline 1 & Suspended solids & $\mathrm{mg} / \mathrm{dm}^{3}$ & 15 \\
\hline 2 & Ammonium nitrogen & $\mathrm{mg} / \mathrm{dm}^{3}$ & 0,95 \\
\hline 3 & Nitrite & $\mathrm{mg} / \mathrm{dm}^{3}$ & 0,8 \\
\hline 4 & Nitrate & $\mathrm{mg} / \mathrm{dm}^{3}$ & 25 \\
\hline 5 & Phosphates & $\mathrm{mg} / \mathrm{dm}^{3}$ & 3,5 \\
\hline 6 & Iron & $\mathrm{mg} / \mathrm{dm}^{3}$ & 0,54 \\
\hline 7 & Chlorides & $\mathrm{mg} / \mathrm{dm}^{3}$ & 831 \\
\hline 8 & Sulphates & $\mathrm{mg} / \mathrm{dm}^{3}$ & 160 \\
\hline 9 & Dry residue & $\mathrm{mg} / \mathrm{dm}^{3}$ & 2000 \\
\hline 10 & Anionic surfactants & $\mathrm{mgO} / \mathrm{dm}^{3}$ & 0,5 \\
\hline 11 & COD & $\mathrm{mgO} / \mathrm{dm}^{3}$ & 80 \\
\hline 12 & BOD & $\mathrm{mg} / \mathrm{dm}^{3}$ & 15 \\
\hline 13 & Petroleum products & & 0,05 \\
\hline
\end{tabular}




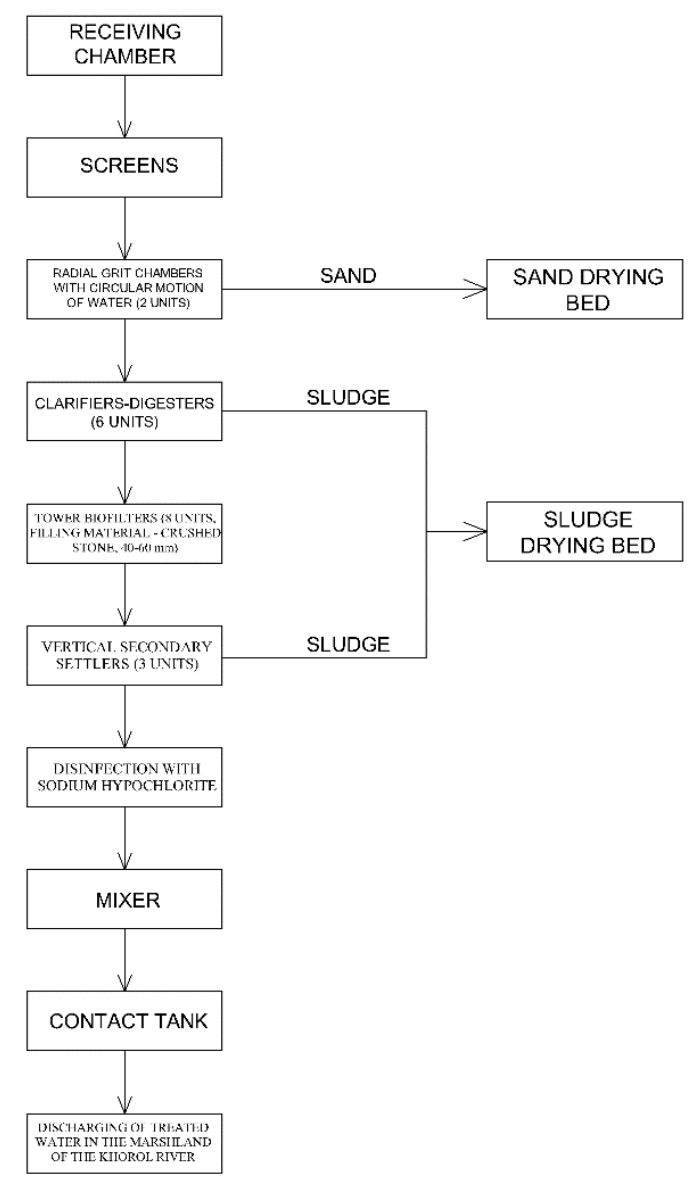

Fig. 1. Wastewater treatment process scheme at Khorol factory for baby food

\section{Assessing efficiency of the WWT plant work.}

WWT (wastewater treatment) plant facilities do not always provide the quality of treated water that is needed according to the regulatory requirements. The chemical laboratory at the treatment plant periodically observe in treated water small exceeding of ammonium nitrogen, phosphates, iron and COD concentrations. Pollutant concentrations, that are presented in this paper, were measured in March 2012 and represent maximum value. Measurement error is equal to the smallest scale division. The conducted studies (UkrNDIEP, 2012) on the composition of wastewater supplied to wastewater treatment facilities show that the most highly concentrated is the fat-containing wastewaters of the veterinary and sanitary plant, which enter the receiving chamber without preliminary purification. This wastewater is characterized by a high amount of ammonium nitrogen, phosphate, COD and fats. In addition, wastewaters of the veterinary and sanitary plant is much mineralized, dry residue is 3180 $\mathrm{mg} / \mathrm{dm}^{3}$. At such loads, the treatment facilities in the current state are not always able to provide a reduction of pollutant concentrations to the regulatory requirements imposed on the quality of treated water released into a water object.

After feeding into the receiving chamber of the treatment facilities, wastewater is pre-treated with mechanical cleaning on the screen and grit chambers. Two parallel working radial grit chambers with circular motion of water are installed at the station. Further, through the measuring tray "Venturi", wastewater is fed into the distribution chamber, from which it is fed into the clarifiers-digesters (Fig. 2).

The sludge that falls out on the bottom of the clarifier is digested in the upper chamber of the digester, where it is fed by a pump. Clarifiers-digesters combine into nodes of two and four facilities. Natural aeration is provided by the difference in the ground levels of the clarifier and the dividing bowl, which results in the air sucking from the atmosphere into the water. Then the water flows successively into the flocculating chamber and the settling chamber, passing through the formed suspended layer. 


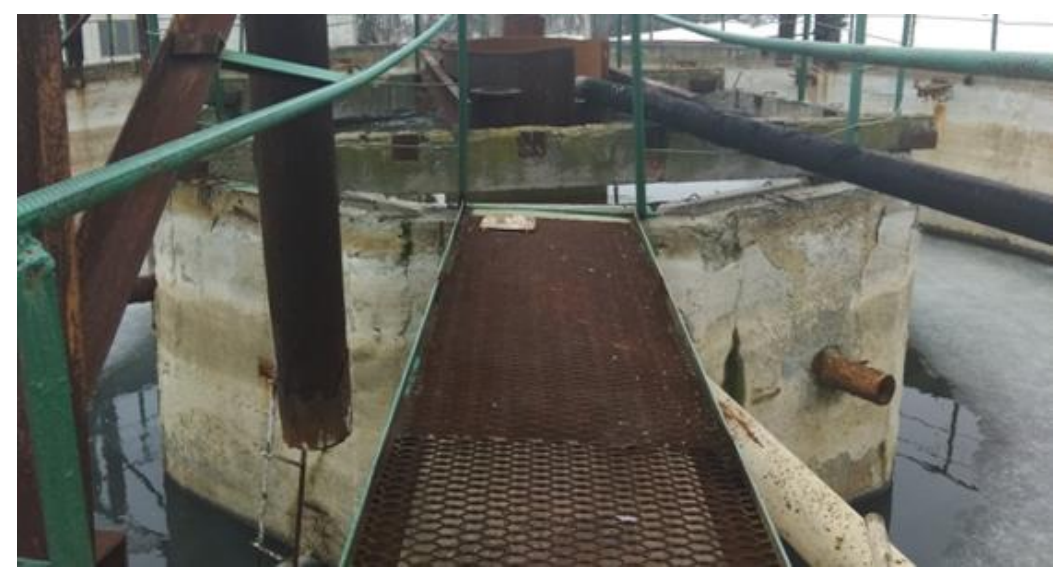

Fig. 2. Clarifier-digester at the wastewater treatment plant of Khorol factory for baby food

At the WWT plant of the Khorol factory for baby food, the clarifiers-digesters are installed in accordance with the typical project 902-2-315 with the size of the facilities $d=12 \mathrm{~m}, \mathrm{~h}=9,48 \mathrm{~m}$ and the size of the clarifiers $d=5 \mathrm{~m}$ and $\mathrm{h}=7,75 \mathrm{~m}$, the technological volume of digester $-540 \mathrm{~m}^{3}$. At the treatment facilities, two nodes of the clarifiers-digesters with the number of units 4 and 2 are installed. The clarifier and digester are separated from each other to avoid the possibility of digested sludge falling into a zone of clarifying and ensures a reduction of concentrations of suspended substances in wastewaters by $70 \%$ and BODт by $15 \%$.

To determinate the efficiency of the clarifiers-digesters work, samples of the wastewater before and after the structures were taken. The results of chemical analyzes are presented in Table 2.

Table 2 - The efficiency of the clarifiers-digesters work

\begin{tabular}{|c|c|c|c|c|}
\hline Pollutants & $\begin{array}{c}\text { Unit of } \\
\text { measuremen }\end{array}$ & $\begin{array}{c}\text { Wastewater before } \\
\text { clarifiers-digesters }\end{array}$ & $\begin{array}{c}\text { Wastewater after } \\
\text { clarifiers-digesters }\end{array}$ & Efficiency of work, \% \\
\hline Suspended solids & $\mathrm{mg} / \mathrm{dm}^{3}$ & 330 & 180 & 46 \\
\hline COD & $\mathrm{mgO} / \mathrm{dm}^{3}$ & 730 & 310 & 58 \\
\hline BOD5 & $\mathrm{mgO} / \mathrm{dm}^{3}$ & 200 & 120 & 40 \\
\hline Ammonium nitrogen & $\mathrm{mg} / \mathrm{dm}^{3}$ & 65,5 & 34 & 48 \\
\hline Chlorides & $\mathrm{mg} / \mathrm{dm}^{3}$ & 536 & 326 & 39 \\
\hline Sulphates & $\mathrm{mg} / \mathrm{dm}^{3}$ & 116 & 111 & 4 \\
\hline Dry residue & $\mathrm{mg} / \mathrm{dm}^{3}$ & 1911 & 1800 & 6 \\
\hline Fats & $\mathrm{mg} / \mathrm{dm}^{3}$ & 24 & 22 & 8 \\
\hline Anionic surfactants & $\mathrm{mg} / \mathrm{dm}^{3}$ & 0,56 & 0,51 & 9 \\
\hline
\end{tabular}

From the results of the chemical analysis presented in Table 2, it can be seen that the content of suspended solids after the clarifiers-digesters decreased by $46 \%$. According to the literature, it is known that these facilities should provide a reduction of not less than $70 \%$. Therefore, the clarifiers do not efficiently work on purification of wastewaters from suspended solids.

After the clarifiers-digesters, the wastewater enters the tower biofilters. At the treatment facilities of the Khorol factory for baby food, there are eight tower biofilters, where $40-60 \mathrm{~mm}$ crushed stone is used as the filling material. The height of the biofilters is $16 \mathrm{~m}$, the diameter is $3 \mathrm{~m}$, and the filling material height is $15 \mathrm{~m}$ (Fig. 3). 


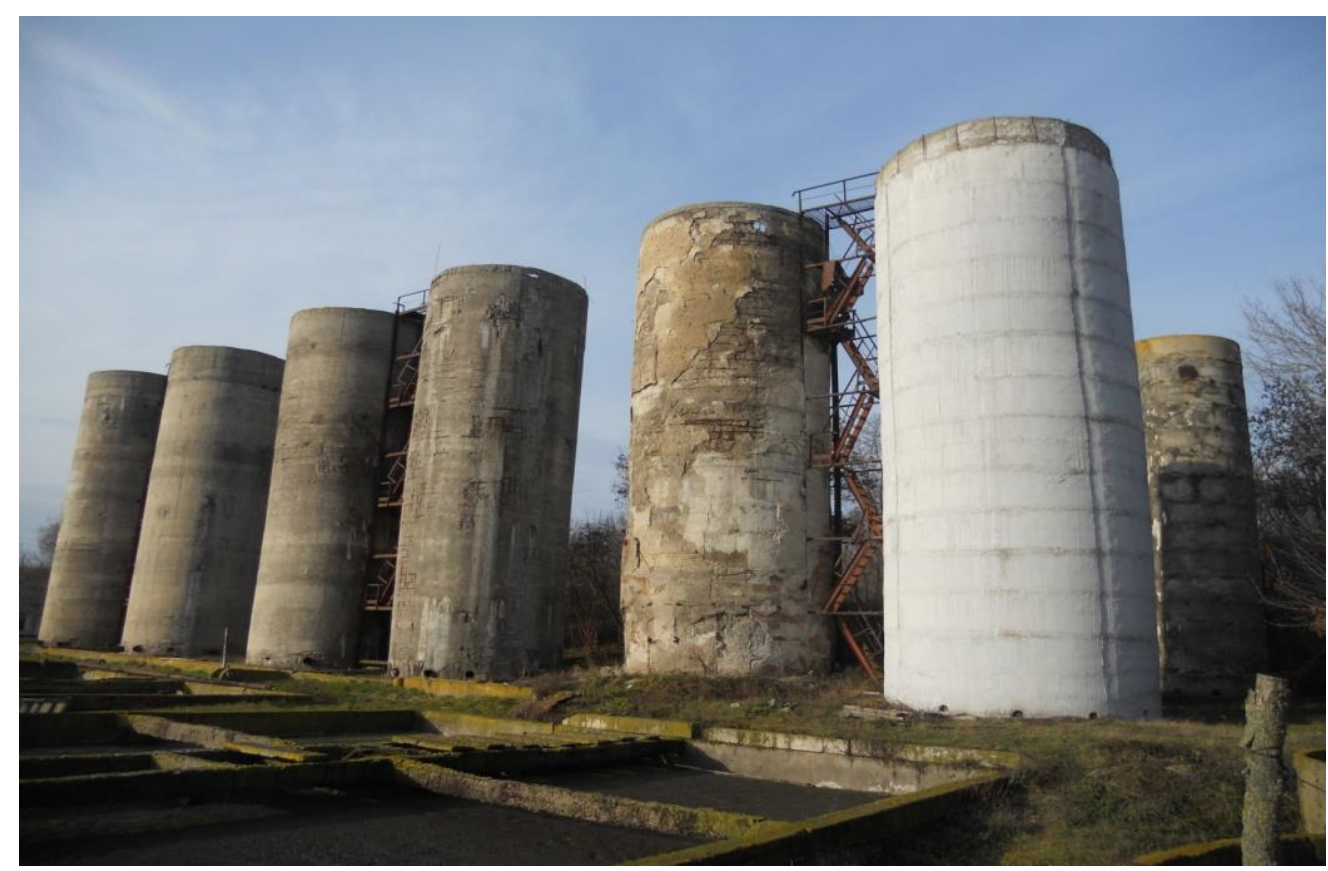

Fig. 3. Tower biofilters of the wastewater treatment plant of Khorol factory for baby food

Chemical analysis of wastewater samples before and after the tower biofilters allows to determine the efficiency of the tower biofilters work. The results are presented in Table 3.

Table 3. Efficiency of the tower biofilters work

\begin{tabular}{|l|c|c|c|c|}
\hline \multirow{2}{*}{ Pollutants } & \multirow{2}{*}{$\begin{array}{c}\text { Unit of } \\
\text { measurement }\end{array}$} & \multicolumn{2}{c|}{ Concentration } & \multirow{2}{*}{\begin{tabular}{c} 
Efficiency of work, \% \\
\cline { 3 - 5 }
\end{tabular}} \\
\cline { 3 - 5 } & 2 & 3 & 4 & 5 \\
\hline $\mathrm{pH}$ & before tower & $\begin{array}{c}\text { after tower } \\
\text { biofilters }\end{array}$ & biofilters & \\
\hline Suspended solids & $\mathrm{mg} / \mathrm{dm}^{3}$ & 180 & 235 & increasing \\
\hline COD & $\mathrm{mgO} / \mathrm{dm}^{3}$ & 310 & 200 & 35 \\
\hline BOD & $\mathrm{mgO} / \mathrm{dm}^{3}$ & 120 & 140 & increasing \\
\hline Ammonium nitrogen & $\mathrm{mg} / \mathrm{dm}^{3}$ & 34 & 16,6 & 51 \\
\hline Nitrite & $\mathrm{mg} / \mathrm{dm}^{3}$ & 1,4 & 12,7 & increasing \\
\hline Nitrate & $\mathrm{mg} / \mathrm{dm}^{3}$ & 0,8 & 99,4 & increasing \\
\hline Phosphates & $\mathrm{mg} / \mathrm{dm}^{3}$ & 14,9 & 12,1 & 15 \\
\hline Sulphates & $\mathrm{mg} / \mathrm{dm}^{3}$ & 111 & 109 & 2 \\
\hline Dry residue & $\mathrm{mg} / \mathrm{dm}^{3}$ & 1800 & 1800 & not changing \\
\hline Anion surfactants & $\mathrm{mg} / \mathrm{dm}^{3}$ & 0,51 & 0.16 & 69 \\
\hline
\end{tabular}

As can be seen from the above results, the concentration of suspended solid after the biofilters increases to one and a half times. At the same time, the value of $\mathrm{BOD}_{5}$ increases, indicating that the filling material of the biofilter is blocked by suspended solids. The removal of dead microorganisms of active sludge out from biofilters with volumetric filling material is one of the most important indicators, which ensures the stable operation of these type facilities. However, the increased value of $\mathrm{BOD}_{5}$ in wastewater after biofilters suggests that along with the dead biofilm removing from the facilities, the living microorganisms of active sludge also remove, and this reduces the oxidizing capasity of biological treatment facilities. 
Wastewater entering the biofilter contains $180 \mathrm{mg} / \mathrm{dm}^{3}$ of suspended solids, and from the practice of the similar facilities operation, the maximum suspended solids content is recommended to 100 $\mathrm{mg} / \mathrm{dm}^{3}$ (Yakovlev, 2006, Kravchenko, 2009, Dolina, 2014). When recommended concentrations are exceeded, clogging of the biofilter is inevitable. Cleaning the filling material and work on the restoration of the facility is a very expensive and time-consuming process, therefore it is often more profitable to replace the filling material. The high content of suspended solids in wastewater entering the biofilter, indicates the unsatisfactory performance of the sediment constructions, in this case, the clarifiers-digesters.

Ammonium nitrogen after biofilters is reduced by $51 \%$, at the same time, the concentration of nitrites and nitrates increases. This suggests the nitrification processes take place, which are typical of biological treatment plants that operate in anaerobic conditions. As a biogenic element, microorganisms of active sludge also use phosphorus, whose concentration after the tower biofilters is reduced by $15 \%$. Also, these facilities provide effective cleaning of synthetic surfactants, the concentration of which decreased by $69 \%$. Concentrations of sulfates and chlorides after biofilters did not change.

An important indicator for the stable operation of biofilters is the active reaction of the medium. Therefore, for example, acidic wastewater from dairy enterprises, when discharged to WWT plants with biofilters, can reduce $\mathrm{pH}$ to 4.5-5. All selected samples of wastewater entering the treatment facilities (baby food factory, veterinary and sanitary plant, city wastewater), had neutral $\mathrm{pH}$ values within $-6,5-8,5$. After averaging in the receiving chamber of the treatment facilities, the wastewater $\mathrm{pH}$ ranged from 7.2 to 7.4. During the survey of treatment plant, waste water was fed on biological filters with an active reaction of medium 8,2-8,3, which negatively affected the work of these facilities.

The analysis of the data obtained allows us to conclude that the biofilters operate at very low levels in almost all indicators, which indicates that the filling material is clogged, there is no air permeability and the biofilm of the filter lacks air oxygen. It is necessary to either clean the filling material, or replace it with a flat polymeric filling material.

After the tower biofilters, wastewater enters three vertical parallel working secondary settlers. The volume of each settlers is $350 \mathrm{~m}^{3}$. The facilities have a cone-shaped bottom structure, which makes it possible to remove the sediment that has settled. Sludge from secondary settlers is carried out 2 times a day. Changing the quality of wastewater after settlers is presented in Table. 4.

Table 4 - Efficiency of the secondary settlers work

\begin{tabular}{|l|c|c|c|c|}
\hline \multirow{2}{*}{ Pollutants } & \multirow{2}{*}{$\begin{array}{c}\text { Unit of } \\
\text { measurement }\end{array}$} & $\begin{array}{c}\text { Concentration } \\
\text { settlers }\end{array}$ & $\begin{array}{c}\text { Efficiency of work, } \\
\text { settlers }\end{array}$ & \\
\cline { 3 - 5 } & unit of $\mathrm{pH}$ & 8,03 & 8,01 & 35 \\
\hline Suspended solids & $\mathrm{mg} / \mathrm{dm}^{3}$ & 235 & 153 & 23 \\
\hline COD & $\mathrm{mgO} / \mathrm{dm}^{3}$ & 200 & 154 & 81 \\
\hline BOD5 & $\mathrm{mgO} / \mathrm{dm}^{3}$ & 140 & 26 & 4 \\
\hline Ammonium nitrogen & $\mathrm{mg} / \mathrm{dm}^{3}$ & 16,6 & 15,9 & not changing \\
\hline Nitrite & $\mathrm{mg} / \mathrm{dm}^{3}$ & 12,7 & 12,7 & increasing \\
\hline Nitrate & $\mathrm{mg} / \mathrm{dm}^{3}$ & 99,4 & 103,7 & 12 \\
\hline Phosphates & $\mathrm{mg} / \mathrm{dm}^{3}$ & 12,1 & 10,7 & 6 \\
\hline Sulphates & $\mathrm{mg} / \mathrm{dm}^{3}$ & 109 & 102 & not changing \\
\hline Dry residue & $\mathrm{mg} / \mathrm{dm}^{3}$ & 1800 & 1800 & 6 \\
\hline Anion surfactants & $\mathrm{mg} / \mathrm{dm}^{3}$ & 0,16 & 0,15 & . \\
\hline
\end{tabular}

The main purpose of the secondary settlers is the separation of wastewater from the biofilms and insoluble suspended solids presented in it. In most cases, the effect of the wastewater purification in settlers is $40-60 \%$. Secondary settlers of Khorol WWT plant provide a reduction of suspended solids 
by $35 \%$ and below. This shows the lack of effective performance of facilities on this indicator. In addition, an overview of secondary settlers has shown that they are in poor construction - the interior walls of the tanks are not smooth, and the fallen pieces of plaster creates an additional hydraulic resistance during sedimentation of the suspended particles. According to the DBN V.2.5-75:2013 (2013) it is necessary once every 2-3 years to inspect and fix the internal walls of the settlers.

To improve the process of suspended solids sedimentation, application of the lamella clarifiers (also so called tube settlers) is proposed.

Evacuation of sludge from secondary settlers is carried out 2 times a day. At the same time, on the surface of the settlers, there are clumps of the floating sludge. Worthy of note that the formation of the floating fraction on the settler's surface is the result of the processes of the accumulated sludge fermentation and rotting, as well as the poor performance of tower biofilters. To improve the settlers work, it is recommended to increase the pumping of sediment from 2 to 3-4 times a day.

After sedimentation, the wastewater is disinfected with sodium hypochlorite and settled in contact tanks. The purified and disinfected wastewater enters the marshy flood plain of the Khorol River. Table 5 shows the results of chemical analyzes of wastewater at the outlet of treatment facilities.

Table 5. Effectiveness the wastewater treatment plant of Khorol factory for baby food

\begin{tabular}{|c|c|c|c|c|c|}
\hline \multirow[b]{2}{*}{ Pollutants } & \multirow[b]{2}{*}{$\begin{array}{c}\text { Unit of } \\
\text { measurement }\end{array}$} & \multicolumn{3}{|c|}{ Concentration } & \multirow[b]{2}{*}{$\begin{array}{c}\text { Efficiency of } \\
\text { work, \% }\end{array}$} \\
\hline & & $\begin{array}{c}\text { into the } \\
\text { WWT plant }\end{array}$ & $\begin{array}{l}\text { out of the } \\
\text { WWT plant }\end{array}$ & $\begin{array}{c}\text { maximum } \\
\text { permissible } \\
\text { concentrations for } \\
\text { discharge }\end{array}$ & \\
\hline $\mathrm{pH}$ & units of $\mathrm{pH}$ & 7,41 & 8,03 & isn't rated & \\
\hline Suspended solids & $\mathrm{mg} / \mathrm{dm}^{3}$ & 330 & 96 & 15 & 71 \\
\hline COD & $\mathrm{mgO} / \mathrm{dm}^{3}$ & 730 & 77 & 80 & 90 \\
\hline $\mathrm{BOD}_{5}$ & $\mathrm{mgO} / \mathrm{dm}^{3}$ & 200 & 17 & 15 & 92 \\
\hline Ammonium nitrogen & $\mathrm{mg} / \mathrm{dm}^{3}$ & 65 & 15,9 & 0,95 & 76 \\
\hline Nitrite & $\mathrm{mg} / \mathrm{dm}^{3}$ & $<0,03$ & 12,4 & 2,0 & increasing \\
\hline Nitrate & $\mathrm{mg} / \mathrm{dm}^{3}$ & 1,38 & 81,2 & 25 & increasing \\
\hline Phosphates & $\mathrm{mg} / \mathrm{dm}^{3}$ & 12,4 & 10,6 & 3,5 & 15 \\
\hline Sulphates & $\mathrm{mg} / \mathrm{dm}^{3}$ & 116 & 102 & 300 & 12 \\
\hline Chlorides & $\mathrm{mg} / \mathrm{dm}^{3}$ & 536 & 800 & 830 & increasing \\
\hline Dry residue & $\mathrm{mg} / \mathrm{dm}^{3}$ & 1900 & 1720 & 2000 & 9 \\
\hline Anion surfactants & $\mathrm{mg} / \mathrm{dm}^{3}$ & 0,56 & 0,15 & 0,5 & 73 \\
\hline
\end{tabular}

From the results obtained, it is clear that the complex of biological treatment facilities provides a high reduction of organic substances by $\mathrm{COD}, \mathrm{BOD} 5$, suspended solids, ammonium nitrogen and anion surfactants. However, even with such efficiency, suspended solids exceed 6 times the maximum permissible concentrations for discharge, 16 times ammonium nitrogen. Phosphate concentrations in treated water decrease slightly compared with the initial wastewater quality. In this case, the phosphate content at the outlet from the treatment facilities exceeds the established norm by 3 times. To reduce phosphates in purified water, it is necessary to carry out a set of measures that are described in (Yakovlev, 2006). Nitrites and nitrates, as the result of the nitrification process, also go beyond the maximum permissible concentrations for discharge, which are $2.0 \mathrm{mg} / \mathrm{dm}^{3}$ for nitrites and $25 \mathrm{mg} / \mathrm{dm}^{3}$ for nitrates.

The complex of biological treatment facilities of the Khorol factory for baby food now receives volume wastewater three times smaller than its design capacity. Reducing the hydraulic load from 3000 to $1000 \mathrm{~m}^{3} /$ day and the change in the composition of wastewater entering the buildings, leads first of all to the ineffective operation of biological treatment facilities. Insufficient cleaning of wastewater in clarifiers-digesters from suspended and organic substances also leads to overloading

Вода і водоочисні технології. Науково-технічні вісті·№1(24) 2019 
of tower biofilters. All this does not always allow to ensure the quality of waste water at the outlet of the facilities to the required norms. The survey of wastewater treatment facilities showed that the quality of wastewater before releasing into a water object does not meet the established norms for suspended solids, ammonium nitrogen, nitrites, nitrates, phosphates, BOD5.

\section{Conclusions.}

In order to solve the described problem, there are several proposals for the intensification of the wastewater treatment facilities:

1. Distribution of sewage on the surface of the tower biofilters. Reliable work of a biofilter can be achieved only with uniformly water irrigation on its surface. Irrigation at the Khorol factory for baby food is carried out by fixed distributors, which does not ensure uniform distribution of water along the surface of the biofilter and requires a significant pressure. The authors of this article offer reactive irrigation with a necessary relatively small pressure $(0.2-1 \mathrm{~m})$, which is one of the advantages of this water distributor. In addition, the jet irrigation eliminates the need to arrange dispensers. The diameter of the openings in radially located pipes is assumed to be $10-15 \mathrm{~mm}$, the distance between the openings increases from the periphery to the center, which ensures more uniform irrigation of the biofilters.

2. Features of the biofilters ventilation at the Khorol factory for baby food. For the proper functioning of the biofilter it is necessary to ensure sufficient oxygen supply. Oxygen air entering the body of a biofilter is spent mainly on the biological oxidation of a part of the pollution that is not transferred from the body of the biofilter. According to the results of the work of the tower biofilters of the Khorol factory for baby food, it can be concluded that during their operation, the filling material was never both cleaned and rinsed out. Since this process is very labor-intensive, slow and very costly, the authors propose to replace the volumetric filling material (crushed stone in the size of 40-60 $\mathrm{mm}$ ) with the plane filling material (plastic blocks). Plastic filling material costs more than crushed stone and others, but it has its advantages: less silting, the better air exchange in them; the high velocity of water flow in a biofilter provides a constant removal of insoluble impurities, which are difficult to oxidize, and dead biofilm.

At present, plastic filling material for biofilters is manufactured both in Ukraine and abroad (Poland, Germany, Italy, etc.). They differ not only in value, but also in design features, types of plastics, etc. It is possible to study this market, pick up inexpensive and efficient filling material for biofilters.

3. Application of technological techniques for improving the wastewater treatment facilities of Khorol factory for baby food. For the reconstruction of the wastewater treatment plant at Khorol factory for baby food, it was proposed to replace the volumetric filling material of the biofilter (crushed stone in the size of $40-60 \mathrm{~mm}$ ) with the plane (plastic blocks). In waiting of the financing of biofilter reconstruction, it is proposed to use a technological method to improve the work of the treatment facilities, namely, clarifiers-digesters and tower biofilter. It is proposed to use recirculation of purified wastewaters with their feeding both into the clarifiers-digesters and into the tower biofilter (Fig. 4).

Before replacing filling material with plastic blocks will be carried out, the supply (recirculation) of wastewater in the amount of $10-20 \%\left(100-200 \mathrm{~m}^{3} /\right.$ day) to the tower biofilter can be made to promote the dilution of treated wastewater, increase the hydraulic load on the biofilter, and simultaneously increase the effect of wastewater treatment (Kovalchuk, 2002). With recirculation the lower layers of the biofilter work much more efficiently. Except this, recirculation of treated wastewater containing a biofilm to the clarifiers-digesters is also possible. The biofilm will not only help to improve water treatment, but also increase efficiency of the clarifying (Kovalchuk, 2002). 


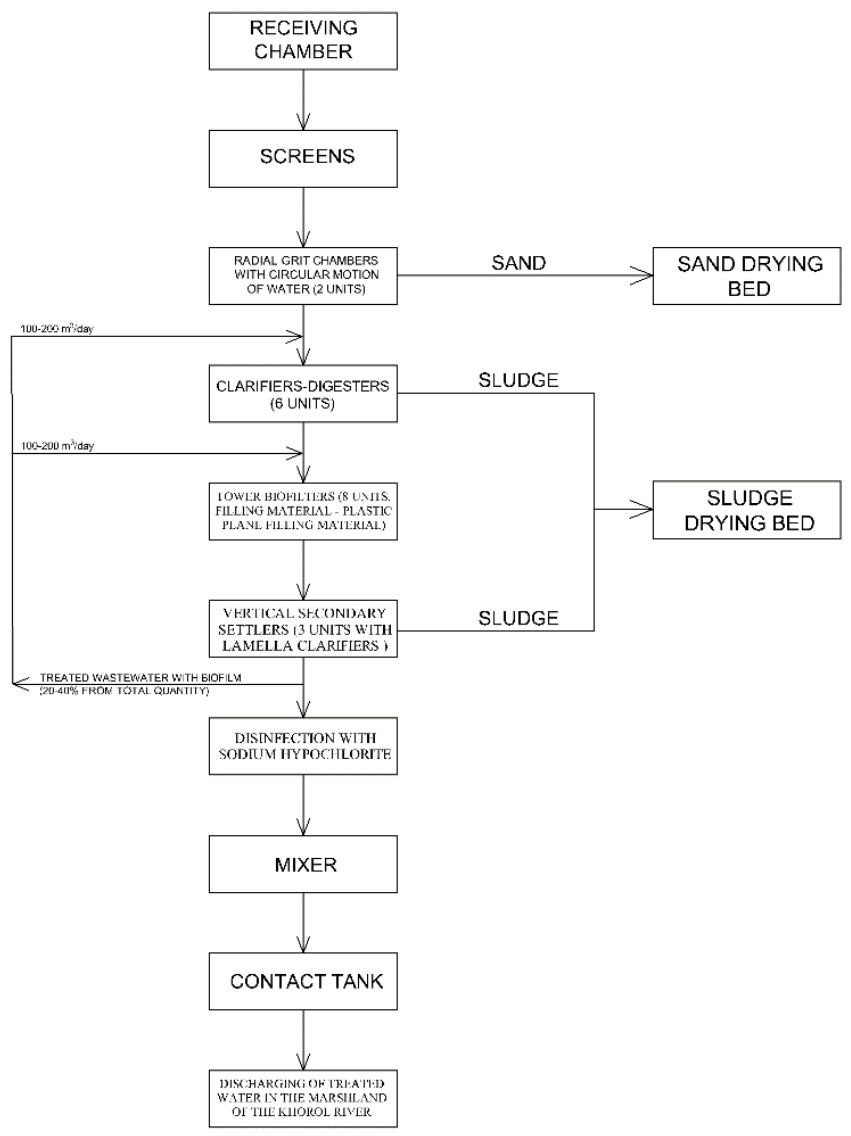

Fig. 4. Improved wastewater treatment process scheme of Khorol factory for baby food

\section{ПІДВИЩЕННЯ ЕФЕКТИВНОСТІ РОБОТИ СТАНЦЇ̈ ОЧИСТКИ СТІЧНИХ ВОД ХОРОЛЬСЬКОГО ЗАВОДУ ДИТЯЧИХ ПРОДУКТІВ ХАРЧУВАННЯ}

\section{Л.Ф. Долина, В.А. Козачина}

Дніпровський національний університет залізничного транспорту імені академіка В. Лазаряна, Дніпро, dolina@pcb.diit.edu.ua

Метою даної роботи є аналіз ефективності очистки стічних вод очисних споруд Хорольського заводу дитячих продуктів харчування та пошук шляхів підвищення ефективності очистки до нормативних вимог по максимально допустимій конщентрацї при скиді очищених стоків.

3 огляду на результати лабораторних дослідів по визначенню конщентрачії забруднювачів у зразках стоків після основних етапів очистки (освітлювачі-перегнивачі, баштові біофільтри, вторинні відстійники) та у випуску очищеної води, зроблено висновок про, зокрема, незадовільну роботу баштових біофільтрів по зниженню ХСК та БПК5 (причини - зменшення подачі стічних вод, незадовільний стан розподільчої системи, замулювання заповнювача біофільтра), вторинних відстійників по зниженню завислих речовин (причини - зменшення подачі стічних вод, незадовільний стан відстійників).

3 метою підвищення очистки стічних вод на очисних спорудах Хорольського заводу дитячих продуктів харчування, були запропоновані наступні кроки: 1) заміна існуючого завантаження біофільтрів (щебінь з розміром фракиій 40-60 мм) на площинне полімерне завантаження, що $\epsilon$ менш замулюваним, створює кращу цииркляцію кисню, сприяє інтенсивнішому виносу відмерлого активного мулу; 2) улаштування системи рециркулящії води для підвищення гідравлічного навантаження на споруди, покращення роботи нижніх шарів біофільтра, 
підвищення ефективності освітлення води у освітлювачі-перегнивачі; 3) улаштування тонкошарових блоків у вторинних відстійниках для інтенсифікації процесу осадження.

Ключові слова: станція очистки стічних вод, біологічна очистка, реконструкція, підвищення ефективності очистки.

\title{
ПОВЫШЕНИЕ ЭФФЕКТИВНОСТИ РАБОТЫ СТАНЦИИ ОЧИСТКИ СТОЧНЫХ ВОД ХОРОЛЬСКОГО ЗАВОДА ДЕТСКИХ ПРОДУКТОВ ПИТАНИЯ
}

\author{
Л.Ф. Долина, В.А. Козачина \\ Днипровский национальный университет железнодорожного транспорта \\ имени академика В. Лазаряна, dolina@pcb.diit.edu.ua
}

Целью данной работы является анализ эффективности очистки сточных вод очистных сооружений Хорольского завода детских продуктов питания и поиск путей повышения эффективности очистки до нормативных требований по максимально допустимой концентрации при сбросе очищенных стоков.

С иелью повышения очистки сточных вод на очистных сооружениях Хорольского завода детских продуктов питания, были предложены следующие шаги: 1) замена существующей загрузки биофильтров (щебень с размером фракиий 40-60 мм) на плоскостную полимерную загрузку, являюшуюся менее заиливающейся, создает лучшую ичикуляцию кислорода, способствует интенсивному выносу отмершего активного ила; 2) устройство системы рециркулячии воды для повышения гидравлической нагрузки на сооружения, улучшения работы нижних слоев биофильтра, повышение эффективности осветления воды в осветителях-перегнивателях; 3) устройство тонкослойных блоков во вторичных отстойниках для интенсификации процесса осаждения.

Ключевые слова: станщия очистки сточных вод, биологическая очистка, реконструкция, повышение эффективности очистки.

\section{References}

Alexander Anim-Mensah, Govind Rakesh. Prediction of Polymeric Membrane Separation and Purification Performances: A Combined Mechanical, Chemical and Thermodynamic Model for Organic Systems. Springer, 2015.

Dolina L.F. Wastewaters treatment from biogenic elements. Dnipro: Kontynent, 2011. [in Russian]. Dolina L.F., Mashykhina P.B. Sludge of wastewaters and natural waters: problems and solutions. Dnipro: Kontynent, 2014. [in Russian].

Kovalchuk V.A. Wastewaters treatment. Rivne: Rivnenska drukarnya, 2002. [in Ukrainian].

Kravchenko V.S. Water supply and sewage. Kyiv: Kondor, 2009. [in Ukrainian].

Likhachev N.I., Larin I.I. Sewage of populated localities and enterprises. Moscow: Stroyizdat, 1981 [in Russian].

Shuokr Qarani Aziz, Sazan Mohammed Ali. Performance of biological filtration process for wastewater treatment: a review. First International conference for Engineering and Innovative Technology ICEIT. At Erbil, Iraq, 2016. - 9 p.

Sewage. External networks and facilities. [DBN V.2.5-75:2013].

UkrNDIEP. Survey of wastewater treatment plant at Khorol factory for baby food. Report. Kharkiv, 2012 [in Russian].

Yakovlev S.V., Voronov Yu.V. Water disposal and wastewater treatment. Moscow: ASV, 2006. [in Russian]. 